National and Global Petroleum Assessment

\title{
Assessment of Mesozoic Tight-Oil and Tight-Gas Resources in the Sichuan Basin of China, 2018
}

$U_{\text {sing a geology-based assessment methodology, the U.S. Geological Survey estimated undiscovered, technically recoverable mean resources }}$ of 1.2 billion barrels of tight oil and 29.1 trillion cubic feet of tight gas in Mesozoic formations in the Sichuan Basin of China.

\section{Introduction}

In 2018, the U.S. Geological Survey (USGS) quantitatively assessed the potential for unconventional (continuous) oil and gas resources in Mesozoic nonmarine clastic rocks in the Sichuan Basin of China (fig. 1) that include tight gas in the Upper Triassic Xujiahe Formation and tight oil in Lower Jurassic lacustrine strata of the Lianggaoshan Formation and the Da'anzhai Member of the Ziliujing Formation. Previous USGS oil and gas assessments in this basin include a 2015 shale-gas assessment in three Paleozoic stratigraphic intervals in the Sichuan Basin (Potter and others, 2015; Potter, 2018) and a 2012 assessment of conventional oil and gas resources in six major Chinese basins (Charpentier and others, 2012).

Chinese national oil companies currently produce tight gas from the Xujiahe (Zhao, Bian, and others, 2013) and tight oil from the Da'anzhai and Lianggaoshan (Chen and others, 2015; Yang and others, 2016) in the central part of the Sichuan Basin. The Xujiahe is a thick fluvial unit that includes three widely distributed coaly gas-prone (Type III) source intervals, each generally 50-150 meters $(\mathrm{m})$ thick and containing numerous coal beds that are a few meters thick (Zou, Tao, and others, 2009; Zhu and others, 2012). These source intervals are alternately stacked with three low-permeability sand reservoir intervals (up to $40 \mathrm{~m}$ thick with individual sand reservoirs 3-8 $\mathrm{m}$ thick) (Zou, Tao, and others, 2009; Zhao, Bian, and others, 2013; Zou, Gong, and others, 2013). The Da'anzhai and Lianggaoshan contain lacustrine black shales that are rich in Type I and II (oil-prone) organic matter (Li and others, 2014) and are interbedded with tight reservoir units that include a shelly limestone (Da'anzhai) and a sandstone (Lianggaoshan) (Yang and others, 2016). The Da'anzhai is 0-60 m thick, and the Lianggaoshan is $0-100 \mathrm{~m}$ thick (Yang and others, 2016).

\section{Assessment Units}

We defined the Triassic Xujiahe Tight Gas Assessment Unit (AU) within the Triassic Total Petroleum System and the Lower Jurassic Tight Oil AU within the Jurassic Total Petroleum System. These AUs (fig. 1) are confined to parts of the Sichuan Basin's relatively undeformed central uplift area in which sufficient thicknesses of these units are present in the subsurface.

The geologic model for the Triassic Xujiahe Tight Gas AU is predicated on burial of Xujiahe coal source rocks to depths of at least 4-5 kilometers during voluminous Mesozoic nonmarine sedimentation. Thermal maturation modeling indicates that these rocks began to generate gas in the Late Jurassic to Early Cretaceous (above wet gas threshold, thermal maturity $\left[\mathrm{R}_{0}\right]$ of $0.6-1.0$ percent) and achieved peak gas generation (1.0-1.3 percent $\left.R_{0}\right)$ by the end of the Cretaceous (Zhao, Wang, and others, 2010; Qin and others, 2018). Short distance migration charged adjacent low-permeability sandstone bodies. The pressure coefficient in the gas reservoirs is 1.1-1.5, indicating strong overpressure (Zou, 2017).

The geologic model for the Lower Jurassic Tight Oil AU comprises generation of oil through Mesozoic burial of oil-prone organic-rich lacustrine shales in the Da'anzhai and Lianggaoshan and short-distance vertical migration into adjacent tight reservoirs. Lower Jurassic organic-rich shales are currently within (and slightly above) the oil window (0.9-1.5 percent $\mathrm{R}_{\mathrm{o}}$ ) (Yang and others, 2016). Chen and others (2015) reported that oil was present in fractures, microfissures, and matrix porosity in the Da'anzhai. The Da'anzhai and Lianggaoshan are separated stratigraphically by only $7-15 \mathrm{~m}$ (Yang and others, 2016), so both are considered producible from a single hydraulically fractured horizontal well. The Lower Jurassic Tight Oil AU includes those areas where the Da' anzhai or the Lianggaoshan, or both, are $15 \mathrm{~m}$ thick and not within a fold/thrust belt.
The Sichuan Basin was strongly influenced by Cenozoic uplift and erosion that caused leakage of hydrocarbons, a fundamental aspect of the geologic models for both AUs discussed above. The basin underwent 1.3-4.0 kilometers of uplift in the past 40 million years (Richardson and others, 2008). Fracturing and faulting associated with this late uplift broke up the strata along the basin margins (especially the northwest margin) and affected the central part of the basin to a lesser degree. There is a hydrocarbon leakage risk associated with this late fracturing and faulting.

Continuous oil and gas accumulations in the United States were used as analogs in this assessment. Table 1 lists the principal input data used for the assessment.

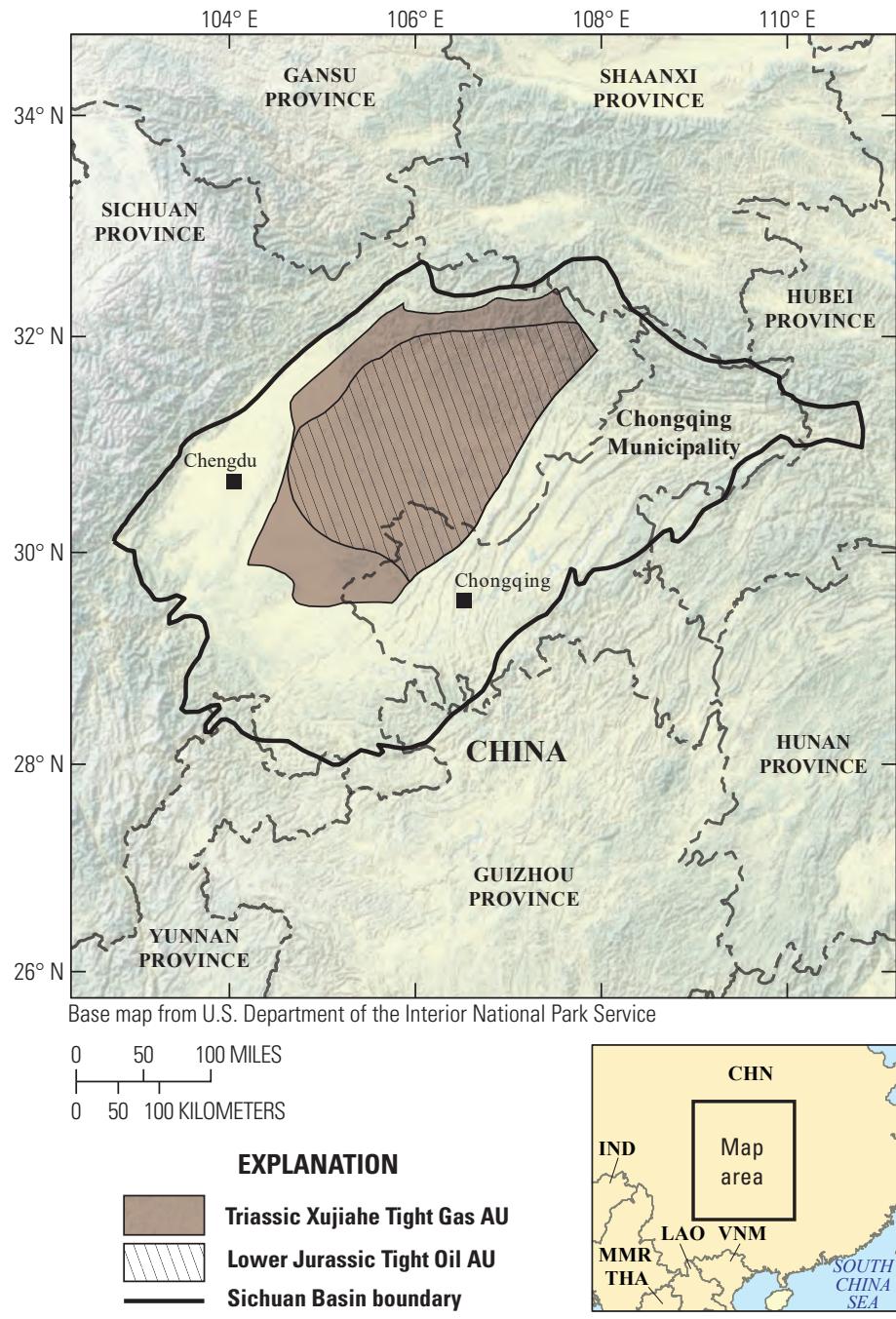

Figure 1. Map showing location of the Sichuan Basin, China, and the locations of the Triassic Xujiahe Tight Gas and Lower Jurassic Tight Oil Assessment Units (AUs). 


\section{Undiscovered Resources Summary}

The USGS quantitatively assessed continuous oil and gas resources in two Mesozoic AUs in the Sichuan Basin of China (table 2). For continuous gas resources, the estimated mean total is 29,065 billion cubic feet of gas (BCFG), or 29.1 trillion cubic feet of gas, with an F95-F5 range from 5,605 to 68,955 BCFG. For continuous oil resources, the estimated mean total is 1,227 million barrels of oil (MMBO), or 1.2 billion barrels of oil, with an F95-F5 range from 268 to 2,743 MMBO. The estimated mean total for natural gas liquids is 138 million barrels (MMBNGL) with an F95-F5 range from 25 to 338 MMBNGL. These resource estimates are for undiscovered, technically recoverable gas, oil, and natural gas liquids resources and do not reflect economically recoverable resources.

\section{Sichuan Basin Assessment Team}

Christopher J. Potter, Christopher J. Schenk, Tracey J. Mercier, Marilyn E. Tennyson, Thomas M. Finn, Cheryl A. Woodall, Heidi M. Leathers-Miller, Kristen R. Marra, Phuong A. Le, Ronald M. Drake II, Michael E. Brownfield, and Janet K. Pitman

\section{For More Information}

Assessment results are also available at the USGS Energy Resources Program website at https://energy.usgs.gov.

Table 1. Key input data for two continuous assessment units in the Sichuan Basin, China.

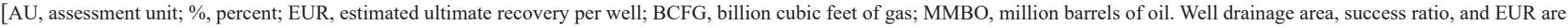
defined partly using U.S. tight-oil and tight-gas analogs. The average EUR input is the minimum, median, maximum, and calculated mean. Shading indicates not applicable]

\begin{tabular}{|c|c|c|c|c|c|c|c|c|}
\hline \multirow{2}{*}{$\begin{array}{l}\text { Assessment input data- } \\
\text { Continuous AUs }\end{array}$} & \multicolumn{4}{|c|}{ Triassic Xujiahe Tight Gas AU } & \multicolumn{4}{|c|}{ Lower Jurassic Tight Oil AU } \\
\hline & Minimum & Mode & Maximum & Calculated mean & Minimum & Mode & Maximum & Calculated mean \\
\hline Potential production area of AU (acres) & 1,000 & $4,000,000$ & $16,400,000$ & $6,800,333$ & 1,000 & $4,500,000$ & $11,800,000$ & $5,433,667$ \\
\hline Average drainage area of wells (acres) & 40 & 80 & 120 & 80 & 120 & 160 & 200 & 160 \\
\hline Success ratio $(\%)$ & 10 & 50 & 90 & 50 & 10 & 50 & 90 & 50 \\
\hline Area untested in AU (\%) & 80 & 90 & 95 & 88.3 & 70 & 80 & 90 & 80 \\
\hline Average EUR (BCFG, gas; MMBO, oil) & 0.2 & 0.7 & 1.5 & 0.734 & 0.04 & 0.085 & 0.2 & 0.091 \\
\hline AU probability & 1.0 & & & & 1.0 & & & \\
\hline
\end{tabular}

Table 2. Results for two continuous assessment units in the Sichuan Basin, China.

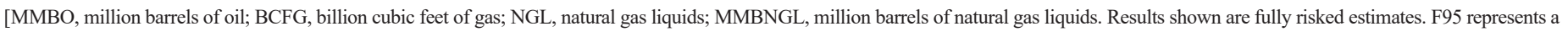
95-percent chance of at least the amount tabulated; other fractiles are defined similarly. Fractiles are additive under the assumption of perfect positive correlation. Shading indicates not applicable]

\begin{tabular}{|c|c|c|c|c|c|c|c|c|c|c|c|c|c|c|}
\hline \multirow{3}{*}{$\begin{array}{l}\text { Total petroleum systems } \\
\text { and assessment units (AUs) }\end{array}$} & \multirow{3}{*}{$\begin{array}{c}\mathrm{AU} \\
\text { probability }\end{array}$} & \multirow{3}{*}{$\begin{array}{l}\text { Accumulation } \\
\text { type }\end{array}$} & \multicolumn{12}{|c|}{ Total undiscovered resources } \\
\hline & & & \multicolumn{4}{|c|}{ Oil (MMBO) } & \multicolumn{4}{|c|}{ Gas (BCFG) } & \multicolumn{4}{|c|}{ NGL (MMBNGL) } \\
\hline & & & F95 & F50 & F5 & Mean & F95 & F50 & F5 & Mean & F95 & $\mathrm{F} 50$ & F5 & Mean \\
\hline \multicolumn{15}{|c|}{ Triassic Total Petroleum System } \\
\hline Triassic Xujiahe Tight Gas AU & 1.0 & Gas & & & & & 5,404 & 23,338 & 66,666 & 28,082 & 20 & 91 & 275 & 112 \\
\hline \multicolumn{15}{|c|}{ Jurassic Total Petroleum System } \\
\hline Lower Jurassic Tight Oil AU & 1.0 & Oil & 268 & 1,062 & 2,743 & 1,227 & 201 & 827 & 2,289 & 983 & 5 & 22 & 63 & 26 \\
\hline $\begin{array}{l}\text { Total undiscovered continuous } \\
\text { resources }\end{array}$ & & & 268 & 1,062 & 2,743 & 1,227 & 5,605 & 24,165 & 68,955 & 29,065 & 25 & 113 & 338 & 138 \\
\hline
\end{tabular}

\section{References Cited}

Charpentier, R.R., Schenk, C.J., Brownfield, M.E., Cook, T.A., Klett, T.R., Pitman, J.K., and Pollastro, R.M., 2012, Assessment of undiscovered conventional oil and gas resources of six geologic provinces of China: U.S. Geological Survey Fact Sheet 2012-3117, 4 p.

Chen Shijia, Zhang Huanxu, Lu Jungang, Yang Yueming, Liu Chaowei, Wang Li, Zou Xianli, Yang Jiajing, Tang Haiping, Yao Yitong, Huang Youlin, Ni Shuai, and Chen Yingying, 2015, Controlling factors of Jurassic Da'anzhai Member tight oil accumulation and high production in central Sichuan Basin, SW China: Petroleum Exploration and Development, v. 42 , no. 2, p. 206-214

Li Zhongping, Huang Fangyan, He Xinwei, Zhang Wanlong, and He Yuting, 2014, Shale-gas reservoir-prediction study in Daanzhai, eastern Sichuan Basin: The Leading Edge, v. 33, no. 5 , p. $526-534$

Potter, C.J., 2018, Paleozoic shale gas resources in the Sichuan Basin, China: American Association Petroleum Geologists Bulletin, v. 102, no. 6, p. 987-1009. [Also available at https://doi.org/10.1306/0828171607817072.]

Potter, C.J., Schenk, C.J., Charpentier, R.R., Gaswirth, S.B., Klett, T.R., Leathers, H.M., Brownfield, M.E., Mercier, T.J., Tennyson, M.E., and Pitman, J.K., 2015, Assessment of Paleozoic shale gas resources in the Sichuan Basin of China, 2015: U.S. Geological Survey Fact Sheet 2015-3053, 4 p. [Also available at https://doi.org/10.3133/fs20153053.]

Qin Shengfei, Li Feng, Li Wei, Zhou Zheng, and Zhou Guoxiao, 2018, Formation mechanism of tight coal-derived-gas reservoirs with medium-low abundance in Xujiahe Formation, central Sichuan Basin, China: Marine and Petroleum Geology, v. 89, part 1, p. 144-154. [Also available at https://doi.org/10.1016/j.marpetgeo.2017.06.032.]

Richardson, N.J., Densmore, A.L., Seward, D., Fowler, A., Wipf, M., Ellis, M.A., Yong Li, and Zhang, Y., 2008, Extraordinary denudation in the Sichuan Basin-Insights from low-temperature thermochronology adjacent to the eastern margin of the Tibetan Plateau: Journal of Geophysical Research, v. 113, B04409, 23 p. [Also available at https://doi.org/ 10.1029/2006JB004739.]
Yang Yueming, Yang Jiajing, Yang Guang, Tao Shizhen, Ni C., Zhang Bin, He X., Lin Jianping, Huang Dong, Liu Min, and Zou Juan, 2016, New research progress of Jurassic tight oil in central Sichuan Basin, SW China: Petroleum Exploration and Development, v. 43, no. 6 , p. 954-964.

Zhao Wenzhi, Bian Congsheng, and Xu Zhaohui, 2013, Similarities and differences between natural gas accumulations in Sulige gas field in Ordos basin and Xujiahe gas field in Central Sichuan Basin: Petroleum Exploration and Development, v. 40, no. 4, p. 429-438.

Zhao Wenzhi, Wang Hongjun, Xu Chunchun, Bian Congsheng, Wang Zecheng, and Gao Xiaohui, 2010, Reservoir-forming mechanism and enrichment conditions of the extensive Xujiahe Formation gas reservoirs, central Sichuan Basin: Petroleum Exploration and Development, v. 37, no. 2, p. 146-157.

Zhu Guangyou, Gu Lijing, Su Jin, Dai Jinxing, Ding Wenlong, Zhang Jinchuan, and Song Lichen, 2012, Sedimentary association of alternated mudstones and tight sandstones in China's oil and gas bearing basins and its natural gas accumulation: Journal of Asian Earth Sciences, v. 50, p. 88-104. [Also available at https://doi.org/10.1016/j.jseaes.2012.01.008.]

Zou Caineng, 2017, Unconventional petroleum geology (second edition): Amsterdam, Elsevier, $500 \mathrm{p}$.

Zou Caineng, Gong Yanjie, Tao Shizhen, and Liu Shaobo, 2013, Geological characteristics and accumulation mechanisms of the "continuous" tight gas reservoirs of the Xu2 Member in the middle-south transition region, Sichuan Basin, China: Petroleum Science, v. 10, no. 2, p. 171-182. [Also available at https://doi.org/10.1007/s12182-013-0264-7.]

Zou Caineng, Tao Shizhen, Zhu Rukai, Yuan Xuanjun, Li Wei, Zhang Guangya, Zhang Xiangxiang, Gao Xiaohui, Liu Liuhong, Xu Chunchun, Song Jiarong, and Li Guohui, 2009, Formation and distribution of "continuous" gas reservoirs and their giant gas province-A case from the Upper Triassic Xujiahe Formation giant gas province, Sichuan Basin: Petroleum Exploration and Development, v. 36, no. 3, p. 307-319. 